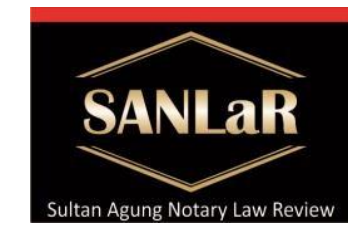

Volume 2 Issue 4, December 2020
Sultan Aqung Notary Law Review

Implementation of Application for Ownership...(Andrian Shidiq)
ISSN 2686-4428

published by

Notarial Law

Universitas Islam Sultan Agung
Semarang

\title{
Implementation of Application for Ownership of State Land in Comparable Railroad Tracks
}

\section{Andrian Shidiq *), Sri Endah Wahyuningsih**) and Ngadino***)}

${ }^{*}$ Student Master of Notary Law, Faculty of Law, Universitas Islam Sultan Agung Semarang, Indonesia

E-mail: shidiq045@gmail.com

$\left.{ }^{* *}\right)$ Lecturer Master of Notary Law, Faculty of Law, Universitas Islam Sultan Agung Semarang, Indonesia

${ }^{* * *}$ Lecturer Master of Notary Law, Faculty of Law, Universitas Islam Sultan Agung Semarang, Indonesia

\begin{abstract}
The purpose of this study is to 1) Know the implementation of land rights applications that are located along the railroad tracks in Pucangsawit Village, Surakarta City. 2) Knowing the obstacles that arise in the implementation of applications for land rights located on the equivalent of railroad tracks in the Pucangsawit Village, Surakarta City. The data used in this research are primary data, secondary data, and tertiary data that can support this study, which are then analyzed using descriptive analytical methods.Based on the results of data analysis, it is concluded that: 1) there is a desire of the community around the equivalent of the railroad tracks in Pucangsawit Village, Surakarta City to have a Freehold certificate. The land he occupies is state land which is beyond the control of PT. KAI Daop Jogjakarta in accordance with the technical recommendations issued by PT. KAI daop Jogjakarta. The basis for the consideration of granting a property certificate from the Surakarta City Land Office is that the community members who apply have controlled and occupied the land for more than 20 years and the land requested is outside the railroad equivalent line whose control is at PT. KAI is in accordance with the recommendation of PT. KAI Daop Jogjakarta. 2) The obstacles faced include, among others, there are still many people along the railroad who do not know the boundaries of land under the control of PT. KAl, the lack of insight and understanding of community members around the railroads regarding land law, especially in filing applications for state land ownership so it needs socialization from related agencies, and there are still complicated procedures and bureaucracy in applying for equivalent state land ownership. railrood tracks that need to be simplifed.
\end{abstract}

Keywords: Implementation; Right of Ownership; State Land; Railroads. 


\section{Introduction}

Soil is an important aspect of human life. All human activities cannot be separated from the existence of land because land is a place for humans to live and continue their life. This situation is increasingly a consequence of the basic understanding and views of the Indonesian people towards land. Most Indonesians view land as a means of living and providing a living so that land has a very important function. ${ }^{1}$

Considering the importance of land for human life, land can be used as a means for the welfare of the Indonesian nation, so that it needs state intervention to regulate it in accordance with Article 33 paragraph (3) of the 1945 Constitution of the Republic of Indonesia which states that earth and water and The natural wealth contained therein shall be controlled by the state and used for the greatest prosperity of the people. We can also see the provisions regarding land in the Law of the Republic of Indonesia Number 5 of 1960 concerning Basic Agrarian Principles or what we usually call the UUPA.

The definition of agrarian includes the earth, water and natural resources contained therein. Within the limits stipulated in Article 48, it even includes space. Namely the space above the earth and water which contains: energy and elements that can be used for efforts to maintain and develop the fertility of the earth, water and natural resources contained therein and other matters related to it. ${ }^{2}$

The UUPA and laws relating to land and their implementing regulations do not explicitly mention and regulate state land. In the UUPA itself the term used for state land is "land directly controlled by the state." The term state land itself appears in the practice of land administration, where the control is carried out by the land authority. ${ }^{3}$

Occupation of lands by people involved in agrarian disputes along PT. KAI of Pucangsawit Village has land problems that must be considered and a government policy is required. The case that occurred in Pucangsawit Sub-district, Surakarta City was that there were several state lands around PT KAI Rail that had not been managed. On this State land several residents built (permanent) walled houses. These houses

\footnotetext{
${ }^{1}$ Hutagalung, Arie Sukanti \& Markus Gunawan. (2009). Kewenangan Pemerintah di Bidang Pertanahan. Jakarta: Rajawali Pers. p. 1 .

${ }^{2}$ Boedi Harsono. (2008). Hukum Agraria Indonesia. Jakarta: Djambatan. p. 6.

3 Julius Sembiring. (2016). Tanah Negara. Jakarta: Kencana. p. 2.
} 
ISSN: 2686-4428

were erected by residents with the understanding that these houses established without having an official land certificate.

In the above case, the builder of this house building cannot be legally justified, even if it is said that the residents who occupy and build buildings along the PT KAI Railroad have violated the rules of agriculture applies in Indonesia. But what happens is the opposite, namely the government does not take action or impose sanctions but allows even in the end give recommendations or give permission to the community to certify the land they control.

\section{Research Methods}

The method used in this writing is descriptive analysis. Descriptive analysis is an analysis that only reaches the descriptive level, namely coalitioning and presenting facts systematically so that it is easier to understand and conclude. The conclusions given are always clear on the factual basis so that everything can always be returned directly to the data obtained. ${ }^{4}$

\section{Results and Discussion}

\subsection{Implementation of an Application for Land Rights Located Along the Railroad in} Pucangsawit Village, Surakarta City

In implementing ownership rights to state land along the railroad tracks, the following stages are required:

1. Preparation phase.

Before carrying out a land application at the Surakarta city land office the applicant makes initial administrative preparations.

- The applicant submits a measurement application to the Land Office.

- The applicant gets the measurement results from the Land Office.

- Submit a letter of application to PT KAI Jogja by attaching the measurement results from the land office.

- Approximately 7 (seven) working days the team from PT KAI conducted a survey of the location of the measurement object.

\footnotetext{
${ }^{4}$ M. Syamsudin. ( 2007). Operasional Penelitian Hukum. Jakarta: RajaGrafindo Persada. p.10.
} 
- Approximately 30 (thirty) days receive a reply letter of recommendation for land application.

\section{Implementation stage}

At this stage the applicant has prepared administrative data in the form of physical evidence and juridical evidence of the requested land.

- The applicant submits a land application to the head of the land office by attaching a recommendation letter from PT KAI and the specified conditions.

\section{Certificate registration stage}

At this stage the applicant submits registration for a certificate of ownership on the equivalent of the PT Railroad Railroad from the Land Office for further certificate registration by including BPHTB tax.

In the implementation of land registration activities for the first time, in this case, the granting of ownership rights to State Land equal to the Railroad of PT KAl from the receipt of documents to the issuance of the certificate itself includes several activities and requires time as regulated in the applicable regulations.

In carrying out land registration for the first time, including in this case the Granting of Ownership of State Land in Comparable Railways, there are rules that must be fulfilled by the City/Regency Land Office, which are called Land Service Standards and Arrangements which are regulated in Regulation of the Head of the Land Agency No.1 2010 concerning Service Standards and Land Management.

The Process Flowchart of the Process of Granting Property Rights/Building Use Rights/Right to Use/Management Rights (Issuance and Registration of SK Hak) Perkaban Number 1 of 2010 concerning Service Standards and Land Management is an outline of the implementation of land registration as mentioned in Attachment II to the Regulation of the Head of Agency Land No. 1/2010 concerning Service Standards and Land Arrangements, both for the process of Granting Property Rights/Building Use Rights/Use Rights/Management Rights (Issuance and Registration of Rights Decrees). 
The procedure for granting ownership rights to state land according to the Regulation of the State Minister for Agrarian Affairs/Head of the National Land Agency number 9 of 1999 concerning Procedures for Granting and Cancellation of Rights to State Land and Management Rights, among others:

1. Applications are submitted in writing individually/collectively if represented by attaching a special brush for processing applications to the land office of the city of Surakarta.

2. The application contains:

- Information regarding the identity of the Petitioner, namely if an individual: name, age, nationality of residence and occupation as well as information regarding his wife/husband and children who are still dependents;

- Information regarding the land which includes: physical data and juridical data, juridical data, namely: sura tgirik, plot letters, proof of land and house release/settlement, court decisions, PPAT deed, deed of relinquishment of rights and papers evidence of other land acquisition. Physical data, namely: land area, location, and size of the building.

3. Stamped stamp of the applicant's statement

4. Letter of recommendation from PT KAI daop Jogja

5. After the application documents are received, the Head of the Land Office:

a. Examine and examine the completeness of dental and physical data;

b. Take notes in the form in accordance with the provisions; provide a receipt for the application documents for the specified form;

c. Notify the applicant to pay the fees required to complete the application with details in accordance with the provisions of the applicable laws and regulations.

6. Furthermore, the Head of the Land Office instructs the Head of the Land Rights Section or appointed officer to examine applications for land rights that have been registered and lands whose juridical data and physical data are sufficient to make decisions as outlined in the Treatise of Land Audit. The land research team examines applications for land rights that have not been 
registered in the official report. The land inspection committee examines applications for rights other than those that are examined as referred to above and set forth in the Minutes of Land Audit.

7. In the event that the decision to grant property rights has been delegated to the head of the Land Office, after considering the opinion of the Head of the Land Legal Relations Section or an appointed official or the Land Research Team or Land Inspection Committee A, the Head of the Land Office will issue a decision to grant the land rights requested or the decision. rejection accompanied by reasons for rejection, taking into account the recommendation from PT KAI daop Jogja.

8. In the event that the decision to grant rights is not delegated to the Head of the Land Office, the Head of the Land Office concerned submits the application documents to the Head of the Regional Office along with the considerations.

9. After receiving the application documents accompanied by opinions and considerations from the Head of the Land Office, the Head of the Regional Office orders the Head of the Land Rights Division to examine and examine the completeness of the juridical data and physical data, and if it is not complete, immediately ask the Head of the Land Office concerned to complete it. Then the Head of the Regional Office issues a decision to grant the right to the land being applied for or refusal along with the reasons for the rejection.

10. In the event that the decision to grant rights is not delegated to the Head of the Regional Office, the Head of the Regional Office submits the application file to the Minister along with his opinion and considerations.

11. After receiving the application documents accompanied by these considerations, the Minister orders the appointed official to examine and examine the completeness of the juridical data and physical data on the requested land by taking into account the opinions and considerations of the Head of the Regional Office, then the Minister shall issue the Decree on Granting Rights to the Land requested or the rejection which accompanied by the reasons for refusal. 
12. The decision to grant the right or the decision to refuse is conveyed to the applicant by registered mail or by other means that guarantee the delivery of the decision to the entitled party.

The authority to grant land rights can be seen in the Regulation of the Head of the National Land Agency of the Republic of Indonesia Number 2 of 2013 concerning Delegation of Authority to Grant Rights to Land and Land Registration Activities to be precise in Article 3 letter $b$ which reads:

"The Head of the Land Office gives a decision regarding the granting of property rights to individuals over non-agricultural land which is not more than $3000 \mathrm{M} 2$ (three thousand square meters)" 5

Meanwhile, the authority to grant land rights of more than $3000 \mathrm{M} 2$ is contained in the Regulation of the Head of the National Land Agency of the Republic of Indonesia Number 2 of 2013 concerning Delegation of Authority to Grant Rights to Land and Land Registration Activities to be precise in Article 7 letter $b$ which reads:

"The Head of the Regional Office of the National Land Agency gives a decision regarding the granting of ownership rights to individuals over non-agricultural land with an area of more than $3000 \mathrm{M}^{2}$ (three thousand square meters) and not more than $10,000 \mathrm{M}^{2}$ (ten thousand square meters)"6

Furthermore, in order to know the procedure and flow of land registration for the first time at the Surakarta City Land Office in more detail. Registration Procedure of State Equivalent State Rail PT. KAI becomes freehold ownership at the Surakarta City Land Office starting from the applicant/PPAT as the attorney of the applicant receiving the complete file after which he submits a registration application to the Surakarta City Land Office Counter with the required requirements. After the registration application documents are declared complete and the payment obligation has been paid by the applicant/PPAT as the proxy, the application files will be submitted to the Head of the Land Infrastructure Section.

\footnotetext{
${ }^{5}$ Regulation of the Head of the National Land Agency of the Republic of Indonesia Number 2 of 2013 concerning Delegation of Authority to Grant Rights to Land and Land Registration Activities Article 3 letter b.

${ }^{6}$ Regulation of the Head of the National Land Agency of the Republic of Indonesia Number 2 of 2013 concerning Delegation of Authority to Grant Rights to Land and Land Registration Activities Article 7 letter $b$.
} 
Meanwhile, the Head of the Land Infrastructure Section will collect and manage physical data on state land in line with the requested PT KAI Rail by taking into account the technical considerations of PT KAI daop Jogja, such as checking the location of land on the map of the Surakarta City Land Office technical instructions issued by PT KAI to obtain data regarding the location of the land, what size it is, what is the position of the building whether there is a house on it or is it still empty land, and the land requested does not overlap with PT KAI which means the land requested is indeed really outside the control of PT KAI daop Jogja. Henceforth, a Measurement Letter is made. The collection and management of physical data on land is important in order to bridge the differences between the requested data and the physical conditions in the field. After the procedure is carried out, it takes about one to two months before a sketch of the location of the requested state land can be published in accordance with the technical recommendations of PT KAI daop Jogja, a sketch drawing is a requirement that must be in place before entering the next stage.

As soon as the collection and management of physical data as well as juridical data are declared complete, the process continues at the trial which will present the applicant either accompanied by PPAT as the attorney or not and presenting the local area stakeholder, this is the head of the village. The trial itself will be chaired by Committee $A$ in order to find the similarities between physical data and juridical data with the admission of applicants who are under oath. Committee $A$ is the committee whose task is to carry out examination, research and study of physical data as well as juridical data both in the field and in the office in the context of completing applications for the granting of Property Rights, Building Use Rights, Use Rights on State land, Management Rights and applications for recognition of land rights.

a. Examining the completeness of the application documents for the granting of Property Rights, Building Use Rights, State Land Use Rights, Management Rights, and applications for recognition of land rights;

b. Conduct research and studies regarding land status, land history and legal relations between the land being requested and the applicant as well as other interests; 
c. Conduct research and physical inspection of the requested land regarding the control, use/condition of the land and the boundaries of the land parcel being requested by taking into account the technical recommendations of PT KAI daop Jogja;

d. Collect information/explanations from the owners of adjacent land;

e. Checking the suitability of the requested land use with the local Regional Spatial Plan;

f. Making report results in the form of Field Inspection Minutes;

g. Conduct hearings based on physical data and juridical data on the results of field examinations, including other supporting data; and

h. Providing opinions and considerations on the application for land rights, as outlined in the Minutes of the Land Inspection Committee signed by all Committee Members A. ${ }^{7}$

Committee $A$ is formed and stipulated by a Decree of the Head of the Land Office. The appointment of the Head of the Land Office for the officials and/or staff who will become Committee $\mathrm{A}$ is based on the main tasks and functions, expertise, experience and/or abilities of those concerned. In Article 3 Perkaban Number 7 of 2007 it is stated that the membership composition of Committee A consists of a Chair who is concurrently a member, a Deputy Chair who is also a member, a member, and a nonmember secretary, then the Chair of Committee A appoints 3 (three) members who are assigned to the field while the members others are in office ${ }^{8} \ln$ practice at the Surakarta City Land Office, the local village head is involved as a member of committee $A$, where the village head is considered the most knowledgeable of the history of the land. As soon as the hearing of Committee $A$ is held, Committee $A$ will make a resume regarding the land requested. . The resume regarding the land is called the minutes of the Land Inspection Committee A, which basically contains:

a. Description of the rights to be determined;

b. Description of the supporting data for the application file;

\footnotetext{
${ }^{7}$ Regulation of the Head of the Land Agency (Perkaban) Number 7 of 2007 concerning Land Inspection Committee, Article 6 paragraph (1).

8 Ibid, Article 3.
} 
c. Legal basis for assigning rights;

d. Description and analysis of the right subject;

e. Description and analysis of the object of rights;

f. Analysis of land rights to be determined; and

g. Conclusion.

The physical data and juridical data that have been included in the minutes of the Land Inspection Committee A (Entry List 201C/DI201C) are then submitted back to the Head of Land Legal Relations for the announcement of the physical data and juridical data, and their validation. Announcement of physical and juridical data is made at the Surakarta City Land Office and the Sub-District Office in accordance with the location of the requested state land. After that the file is submitted to the Head of the Land Office as a recommendation to issue a Decree on Granting land rights.

After the Decree on granting land rights is signed by the Head of the Land Office, then for attachments to the Validation Process for Land and Building Rights Acquisition Fees (BPHTB) in the Surakarta City Government. After the Validation process is carried out, the files are returned to the KASI for Land Legal Relations to be recorded in a land book signed by the Head of the Land Office. The final stage is filling in the land registration administration carried out by the KASI of Land Law Relations and sewing of land books with situation pictures/measuring letters, where the land book with a situation picture/measuring letter that has been sewn is the final result of a series of land registration for the first time which is named land certificate

Regarding the registration period and registration fee for Freehold Lands in the State Equivalent to PT KAI Rail at the Surakarta City Land Office, the basis for the arrangement is in accordance with the registration period and registration fee for state land ownership in accordance with Perkaban Land Service and Regulation Standards No.1 of 2000.

In the Land Service and Regulatory Standards above, it is stated that the period of first registration for non-agricultural State Land, which is not more than $2000 \mathrm{~m} 2$, is 38 days. However, in practice, the first registration process for State Land in the city of Surakarta cannot absolutely be completed within 38 days from the time the application documents enter the counter until the issuance of the certificate. As explained by the 
Kasi of Land Legal Relations at the Surakarta City Land Office, Mr. AGUS SUPRAPTA, SH, MKN:

The Head of the Land Office Decree will later be used as the basis for the BPHTB validation process in the Surakarta City Government. For the duration of the validation process in the city government of Surakarta \pm 1 week after the process is completed then it will be registered at the Land Office, which is listed in Perkaban 1/2010, which is 38 days $^{\prime \prime}{ }^{9}$

Whereas in the Big Indonesian Dictionary itself gives the meaning of the word "standard" as 1) a certain measure used as a benchmark, and 2) something that is considered a fixed value so that it can be used as a measure of value. ${ }^{10}$

The implementation of granting ownership rights over state land in the city of Surakarta obliges the applicant to pay a number of costs to be incurred for the first land registration. As for Appendix II of Perkaban Number 1 of 2010 concerning Service Standards and Land Management, it is stated that the costs to be incurred in the framework of Land Registration for the First Time, in this case the granting of ownership rights over state land to Individuals, are in accordance with the provisions of the Government Regulation regarding the types and rates of the type of non-tax state revenue that applies to the National Land Agency of the Republic of Indonesia.

3.2 Obstacles faced in the process of applying for ownership rights over state land in proportion to the pt kai railroad in the palm grove of Surakarta city

a. The facilities and human resources of the SPSS sector are still lacking, this causes the measurement process to be very long.

b. The system for applying for ownership rights over state land has not been maximally and transparently socialized.

c. There is a lack of land surveying officers at the Surakarta city land office so that they have to queue to wait for their turn to apply for measurement. This results in relatively longer time for the process of obtaining a certificate of ownership of state land.

\footnotetext{
${ }^{9}$ Interview with the Head of Land Law Relations at the Surakarta City Land Office Mr. AGUS SUPRAPTA, SH, MKN, on April 19, 2018.

${ }^{10}$ Kamus Besar Bahasa Indonesia, diakses di http://kbbi.web.id pada 25 November 2020 di Surakarta.
} 
d. The lack of insight and understanding of community members around the railroad equivalent regarding land law, especially in filing applications for property rights over state land so it needs outreach from related agencies,

e. There are still complicated procedures and bureaucracy in applying for ownership rights over state land along the railroad tracks that need to be simplified.

\section{Closing}

Based on descriptions from the beginning to the end regarding the implementation of the application for state land rights on the equivalent of the railroad tracks in Pucangsawit Sub-District, Surakarta City, it can be concluded as follows the willingness and initiative of the community to apply for a certificate of ownership rights. The land occupied is state land that is completely outside the control of PT. KAI daop Jogja in accordance with the technical recommendations issued by PT KAI daop jogja. want to be arranged to avoid a slum environment, according to the measurement results from the land office of the city of Surakarta, the land is outside the PT KAI railroad line, the applicant obeys the regulations and is able to carry out his obligations, the area is suitable as a place to live. The obstacles in the application for the right to hold the state on par with the railroad in Pucangsawit Village by the Surakarta City Land Office are: there are still many people on the same line as PT KAl's tracks who do not know the boundaries of land controlled by PT KAI. Lack of knowledge and understanding of community members about land law, especially in the application process for land rights on the same road as PT KAI, so there is a need for information and socialization from the Land Office and related institutions. The need for simplification of procedures and bureaucracy so that the process carried out in the application for land rights along the railroad tracks does not take too long.

\section{References}

Books:

[1] Hutagalung, Arie Sukanti \& Markus Gunawan. (2009). Kewenangan Pemerintah di Bidang Pertanahan. Jakarta: Rajawali Pers. 
[2] Boedi Harsono. (2008). Hukum Agraria Indonesia. Jakarta: Djambatan.

[3] Julius Sembiring. (2016). Tanah Negara. Jakarta: Kencana.

[4] M. Syamsudin. ( 2007). Operasional Penelitian Hukum. Jakarta: RajaGrafindo Persada.

Internet:

[1] Kamus Besar Bahasa Indonesia, diakses di http://kbbi.web.id pada 25 November 2020 di Surakarta.

\section{Regulation:}

[1] Regulation of the Head of the National Land Agency of the Republic of Indonesia Number 2 of 2013 concerning Delegation of Authority to Grant Rights to Land and Land Registration Activities Article 3 letter b.

[2] Regulation of the Head of the National Land Agency of the Republic of Indonesia Number 2 of 2013 concerning Delegation of Authority to Grant Rights to Land and Land Registration Activities Article 7 letter $b$.

[3] Regulation of the Head of the Land Agency (Perkaban) Number 7 of 2007 concerning Land Inspection Committee, Article 6 paragraph (1).

Interview:

[1] Interview with the Head of Land Law Relations at the Surakarta City Land Office Mr. AGUS SUPRAPTA, SH, MKN, on April 19, 2018 